\title{
The EFL Teacher: A Cultural Mediator and A Facilitator
}

\author{
Karim Karmi \\ The Institute of Applied Humanities in Zaghouan 1121, University of Tunis, Tunisia
}

\begin{abstract}
The new realities of this era of globalization have made it imperative to reconsider the way foreign languages are taught. Teaching a foreign language effectively must be preceded with a thorough analysis of the learner's needs. Today's learner is a future global citizen who will have to effectively integrate into the global community and be part of a fiercely competitive global job market. Language teachers must understand that a teacher-centred class where the predominant concern is with grammar and vocabulary does no longer live up to expectations. The language teacher required in this era of globalization should be conceived of as an agent able to effectively play the role of a cultural mediator. The language teacher must also be a facilitator able to walk the learner through the process of developing his/her interpersonal and communication skills.
\end{abstract}

Keywords: Language teacher; Cultural mediator; Facilitator.

DOI: $10.7176 / \mathrm{JEP} / 10-17-09$

Publication date: June $30^{\text {th }} 2019$

\section{Introduction}

As language teachers, we do not differ on the fact that we must teach from objectives. However, one must admit that our understanding of the concept of objectives must be revisited and updated. In today's globalized world, objectives should no longer be simplistically defined as the linguistic competences that the learner should attain by the end of a language unit. Objectives should be thought of in a more comprehensive way. They should encompass the skills and competences learners will need in their futures and daily lives. Being a global citizen requires that the individual be able to communicate while taking into account cultural differences.

\section{Impact of Globalisation on EFL teaching}

Globalization and the emergence of English as a lingua franca have profoundly impacted the teaching of English as a foreign language (EFL).Li and Dann (2006:8) confirm that EFL teachers must understand that they have already entered the biggest language and linguistic revolution ever. Revolution means far reaching changes and new perspectives. Therefore, it is essential that language teachers update their learning and teaching beliefs so that they can keep pace with the requirements of this new era. Learning has become ubiquitous and possible at the click of a button. The emergence of new concepts such as mobile learning and situated learning is a case in point. Vavoula (2005) defines mobile learning as any sort of learning that happens when the learner takes advantage of the learning opportunity offered by mobile devices. Lave and Wenger (1990) explain that learning is situated as it normally takes place within activity, context and culture. Language teachers must understand that they are no longer regarded as agents landed with delivering content. Learning can take care of itself if the teacher manages to create environments conducive to learning. Daoud (2017) confirms that teachers of English are no longer tasked with teaching English. He explains that they are put in charge of helping people communicate in English. In the same vein, Daoud (2017) warns that if teachers fail to properly dismiss the aforementioned mission, they will lose the learner. Losing the learner means being unable to maintain their motivation and keep them engaged.

\section{Redefining the roles of the EFL teacher}

Motivating learners is one of the major challenges facing EFL teachers. However, one must admit that it is quite common to start a language teaching programme with motivated learners who lose interest as the course goes along. Daoud (2017) acknowledges that maintaining the learner's motivation is a very challenging task that places great demands on the teacher. Today's EFL teacher of English should be conceived of as a cultural mediator in charge of helping learners develop the skills they will need in their future. Being an efficient EFL teacher means succeeding in playing the roles of both, a cultural mediator and a facilitator. However, this is not possible unless we fully understand what we mean by a cultural mediator, and what we mean by a facilitator. Understanding the concept of cultural mediator must be preceded with a thorough discussion of what we mean by culture in EFL teaching. It must also be preceded with some thoughts on how culture can be introduced in a language class.

\section{Defining culture in EFL teaching}

The complex nature of the concept of culture explains why its definition has not enjoyed total consensus. Scarino (2010:327) confirms that culture is a complex system of concepts, attitudes, values, beliefs, conventions, behaviours, practices rituals and lifestyles of the people who make up a cultural group. In language teaching, 
researchers confirm that language and culture are inextricably intertwined and cannot be separate (Fatini,1995 ; Mitchell \&Myles, 2004). Benett (1997) uses the term fluent fool to describe a person who speaks a foreign language fluently, but without understanding its cultural dimension. Tomlinson \& Mashuara( 2004:8) define cultural competence as the ability to converse with members of the target culture, understand and explain their perspectives and practices. The various definitions provided in the literature agree that the concept of culture in language teaching usually refers to the sociolinguistic and pragmatic competence that the language learner must develop (Boers \& al 2004). Deda (2013:63) defines pragmatic competence as the ability to comprehend and construct utterances according to the social and cultural circumstances in which the communication occurs. Wardhaugh (2002:2) clarifies that knowing a foreign language is conditional on knowing the rules and principles of saying and doing things .He warns against the simplistic view of language as mere knowledge of words sentences and structures.

\subsection{The place of culture in the department of English}

Examining the syllabi taught at the departments of English within Tunisian universities shows the existence of serious misconceptions about the concept of culture. Culture is being simplistically equated with history, or the so-called civilization. Almost, not attention is being paid to the way native speakers of English speak in day-today situations. In spite of its overriding importance, the idiomatic aspect of the language is hardly present in the Curriculum. Boers et al (2004: 376) state that idioms are pervasive in real life as part of the culture. Therefore, they confirm that learners must build up their knowledge of idioms if they want to survive in real communication settings. Another problem in the Tunisian departments of English lies in the fact that varieties of English and other accents are being totally overlooked. There is an unjustified obsession with Received Pronunciation (RP). Crystal (2003) stresses the need to introduce EFL learners to different accents and varieties, and not be too reliant on RP. Crystal (2002) explains that speakers of RP are only a small minority of English speakers in Britain, and a tiny fraction of all native speakers of English. He adds that it is important to enable $21^{\text {st }}$ century learners of English to understand varieties of accents so that they can effectively communicate with most speakers of English. As far as the teaching of English varieties and accents is concerned, one can argue that this problem is not confined to the Tunisian context. Bieswanger (2008) acknowledges that varieties do not usually receive enough attention in university programs for prospective teachers.

\subsection{Culture: a foreign concept in the Tunisian EFL context}

The fallacious approach to the introduction of culture in the Tunisian Departments of English is having its harmful ripple effects on the entire Tunsian EFL context. Universities are producing high school teachers of English who have learnt and understood almost nothing about English culture. Hermassi (2016) confirms that culture is marginalized in the Tunisian EFL context. He carried out a study in which seventy high school teachers took part. Hermassi (2016) concludes that 45 percent of high school teachers lack the necessary knowledge of English culture. He acknowledges that most high school teachers find the concept of culture vast and ambiguous .He ascribes the problem to the fact that the element of culture was absent during their training at university. In this regard, he states

It would be unrealistic to expect from Tunisian teachers to enthusiastically engage in culture teaching when almost half of them think they lack the knowledge, experience and training required to do so. (p.114)

\subsection{The EFL teacher as a cultural mediator}

Playing the role of a cultural mediator effectively is conditional on having a good command of the language and a good knowledge of its culture. Being familiar with English culture means having developed the necessary pragmatic and sociolinguistic competences. Familiarity with English culture entails knowing how the language is used in day-to-day situations. The language teacher must also be aware of the main differences between the main varieties of English. In other words, Tunisians EFL teachers must at least have an idea about the accents most common in Britain. Jabeur (1998) summarized the set of the aforementioned competences as the model of the native speaker that has to be present in the classroom. It should be noted that acquiring these credentials is not possible if the prospective teacher is deprived of the chance to spend some time in an Anglophone country. Kashru (1992) confirms that learning the cultural aspects of communication is conditional on visiting the foreign country and spending some time in it. In Tunisia, for reasons mainly related to budget cuts, the summer schools that used to take place in Britain are now organized in Tunisia. One can argue that bringing some native speakers to discuss some films and movies with prospective teachers of English stands no comparison with what they can learn from the experience of spending some time in Britain or the United States.

\section{The EFL teacher as a facilitator.}

The advent of the communicative language teaching (CLT) has brought the concept of facilitator to the fore. 
Tunisian EFL teachers do not differ on the fact that teaching effectively means necessarily being a facilitator in one's classroom. However, it should be noted that our understanding of the word facilitator is simplistic, superficial and incomplete. The word facilitator should not be thought of as a mere role to be played to help cover the tasks and activities of a language unit. Our understanding of the word facilitator must become more exhaustive. A facilitator should mean a language teacher who is able to promote autonomy among his/her learners. In other words, a facilitator should help learners take charge of their own learning. Translating learner autonomy into practice requires that the teacher effectively walk his/her learners through the process of exploring their learning strategies. A facilitator is also an agent in charge of helping people develop their interpersonal skills. Soontiens (2004) confirms that a language class is a favourable opportunity to help people develop their interpersonal skills.

\subsection{How can the EFL teacher be a facilitator?}

University teachers in the departments of English are well aware of the fact that most Tunisian English graduates have difficulties finding jobs as they lack the necessary skills that the job market is after. Houas et al( 2012) acknowledge that Tunisian graduates lack the skills demanded by employers. The set of skills that graduates need to find their way on the job market has become referred to as $21^{\text {st }}$ century skills .Critical thinking, communication, collaboration and creativity $4 \mathrm{Cs}$ ) are skills that university graduates must possess if they are going to find their way on today's fiercely competitive global job market. Most Tunisian university teachers are willing to help their learners develop the aforementioned skills. However, the long syllabi they need to cover deter them from doing so. Most teachers are worried about the fact that opening up the space for the learner to experiment with the 4Cs will come at the expense of the content they are teaching. One can argue that this concern is unjustified. The aforementioned skills can be smoothly integrated in literature, civilization and linguistic classes if the teachers manages to effectively make use of project based learning (PBL) and Problem Based learning approaches. The aforementioned approaches can be defined as instructional approaches that engage learners in problem solving tasks and collaborative projects carried out in the foreign language and targeting real world problems. Problem based learning (PBL) is an instructional approach premised upon the assumption that learning takes place when the learner addresses real world problems. Daoud (2017) confirms that language learning takes place when the teacher manages to bring the world into the classroom. Daoud (2017) stresses that language teaching must simulate real life situations. In the same vein, Harmer (1998) highlights that learning a foreign language takes place when the learner uses it to solve real world problems. One must admit that, in practice, integrating twenty first century skills into a literature or history class is a very demanding task that places great demands on the teacher. Aydinli (2007) confirms that the use of problem based learning requires that the teacher effectively act as a cognitive model and coach. He adds that the use of Project based learning in a language class is not less challenging as it takes a high degree of planning and organization. Competent EFL teachers are the outcome of sound teacher education programmes. The next section attempts to shed light on what needs to be improved upon in the Tunisian departments of English.

\section{Rethinking EFL teacher education programmes in Tunisia.}

It is not possible for high school teachers to teach communicatively if they were not taught that way. McMillan (1985) emphasizes that prospective teachers teach as they were taught not as they were taught to teach. Promoting learner autonomy among learners is conditional on having autonomous teachers (Daoud, 2017). However, one can argue that the way prospective teachers are taught fails to instil into them any sense of autonomy. One must warn that, even the departments of English have not been immune from students asking for private tutoring, which is a sign of overreliance on the teacher. The long syllabi that university teachers are required to cover make them fall into the trap of delivering content. Racing against time to finish the programme drives all kinds of interaction and communication away from the classroom. Belhaj and Abderahmen (2015:57) warn that the vast majority of Tunisian academics perceive teaching as an activity primarily focused on student knowledge and transmissions. University curricula must be made lighter so that teachers find the necessary amount of time to help students experiment with different indispensable life skills. Teaching in a communicative and interactive way is not possible in the existence of very large numbers of students; scheduling micro teaching classes becomes impossible. As a result, even pedagogy and TEFL classes, are taught in a theoretical way with hardly any room left for practice. Bringing about positive reforms to the teaching of English in the Tunisian departments of English is not possible in the absence of a sound language policy. Daoud (2011) ascribes the problem to the lack of a comprehensive language policy and a sound implementation strategy. He explains that introducing effective reforms in the field of ELT in Tunisia will only be possible if educators and applied linguists, in particular, get involved in language policy matters.

\section{Conclusion}

Globalization and the emergence of English as a lingua franca have made it imperative to redefine the roles of 
the EFL teacher. The latter should be able to effectively play the role of a cultural mediator and a facilitator. However, it should be noted that producing EFL teachers competent in this regard is conditional on the existence of sound teacher education programmes. Providing prospective teachers with adequate tailor made training will not be possible in the absence of a sound language policy. Reforming language education is a complex process that has to be top down and bottom up at the same time.

\section{References}

Aydinli,J.M.( 2007). "Problem-Based Learning and Adult English Language Learners." Center for Applied Linguistics. Retrieved from http://www.cal.org/caela/esl resources /briefs/Problem-based.

Belhaj , A., \& Abderahmen , M.(2015). The portrait of Good University Teacher as perceived by Tunisian students. International Journal of Higher Education, 4 (3) 57-62.

Bennet, M.(1993). "How Not to Be a Fluent Fool: Understanding the Cultural Dimension of Language". The Language Teacher, 27 (9).

Bieswanger, M.(2008).Varieties of English in current English language teaching. Stellenbosch Papers in Linguistics, 38, 27-47.

Boers, F.,Eyckmans J., Demecheleer M. (2004). Cross-cultural variation as a variable in comprehending and remembering figurative idioms. European Journal of English Studies, 8(3), 375-388.

Crystal, D. (2003). English as a global language. Cambridge, UK: Cambridge University Press.

Daoud, M. (2011). The sociolinguistic situation in Tunisia: language rivalry or accommodation?. International Journal of the Sociology of Language, 2011(211), pp. 9-33.

Daoud, M. (2017).Teaching English in Turbulent Times: Curriculum-Savvy teachers for Curriculum Success and Sustainability. Plenary at the BALL annual meeting,Leeds,UK.

Deda, N. (2013). The role of Pragmatics in English Language Teaching. Pragmatic Competence. Academic $\begin{array}{llllll}\text { Journal } O f \quad \text { Interdisciplinary } & \text { Studies, } & 2(4), & \text { Retrieved }\end{array}$ http://www.mcser.org/journal/index.php/ajis/article/view/106/263.

Fantini,E.(1995). "Introduction: Language, Culture and World View."International Journal of Intercultural Relations 19, 2:143-153.

Harmer, J. (1998). How to teach English: An introduction to the practice of English language teaching. Harlow: Longman.

Hermassi, T. (2016). 'Teacher cognition on the place of culture in English education in Tunisia.' Journal of Society, Culture\&Language,4(2):106-116.

Haouas, 1.,Sayre,E. \& Yagoubi,M.,(2012).Youth Unemployment in Tunisia:Characteristics and Policy Responses.Topics in Middle Eastern and African Economies, 14 (1),pp.395-415.

Jabeur,M.(1999). 'English, globalisation and Tunisia.' English in North Africa.

Kachru, B. (1992). World Englishes: approaches, issues and resources. Language Teaching, 25(01), p.1.

Lave, J., \& Wenger, E. (1990). Situated Learning: Legitimate Periperal Participation. Cambridge, UK: Cambridge University Press.

Li,W.,\&Dan, BC.(2006).The Impact of Globalization and the Internet on English Language Teaching and Learning.Helongjiang University,Harbia.

McMillan, Catherine,M. (1985). "Do Teachers Teach as They Were Taught to Teach ?' American Reading Forum Yearbook 5:85-87.

Mitchell, R. and Myles, F. (2004). Second language learning theories. London: Hodder Arnold.

Scarino, A. (2010). Assessing intercultural capability in learning languages: A renewed understanding of language, culture, learning and the nature of assessment. Modern Language Journal, 94(2), 324-329.

Soontiens, W. (2004). When in Rome: The realities of skill development in an 'Anglo' educational environment. Journal of Research in International Education, 3(3), 301-317.

Tomlinson, B., \& Mashuara, H. (2004). Developing cultural awareness. Modern English Teacher, 13 (1), 5-11.

Vavoula ,G.(2005). A study of Mobile Learning Practices. Retrieved from http://www.mobilearn.org/download/results/public-deliverbles/MOBIlearn_D4.4_Final.p

Wardhaugh,R.(2002).An introduction to sociolinguistics (Fourth Ed.). Oxford: Blackwell Publishers 